\title{
Association between polymorphism of the G-protein $\beta 3$ subunit C825T and essential hypertension: an updated meta-analysis involving 36,802 subjects
}

\author{
Huan Zheng ${ }^{1,2,3}$, Huifeng $\mathrm{Xu}^{1}$, Bin Cui ${ }^{2,3}$, Nanzi Xie ${ }^{1}$, Zhi Wang ${ }^{2,3}$ Ming Luo ${ }^{1, \star}$ \\ ${ }^{1}$ Geriatrics Department, Tongji Hospital Affiliated to Tongji University, Shanghai, China \\ 2 School of Life Science, Arizona State University, Tempe, USA \\ ${ }^{3}$ Center for Evolutionary Medicine and Informatics, Arizona State University, Tempe, USA
}

\begin{abstract}
Purpose: The G-protein $\beta 3$-subunit gene C825T polymorphism (GNB3-C825T) has been reported to be associated with essential hypertension $(\mathrm{EH})$, but results from previous studies are conflicting. The present study aimed at investigating the association between this polymorphism and risk of $\mathrm{EH}$ using a meta-analysis on the published studies.

Materials and Methods: PubMed, Embase, CBM (China Biological Medicine Database), Wanfang and VIP databases were searched to identify eligible studies published in English and Chinese before March 2013. Data were extracted using standardized methods. The association was assessed by the odds ratio (OR) with 95\% confidence intervals (CI). Begg's test was used to measure publication bias. Results: A total of 40 case-control studies containing 16,518 EH patients and 20,284 controls were involved in this meta-analysis. Overall, a significant association was found between GNB3 C825T polymorphism and risk of EH when all studies were pooled with a random-effects model for $\mathrm{T}$ versus $\mathrm{C}(\mathrm{OR}=1.09,95 \% \mathrm{CI}$ : 1.04-1.19). In the subgroup analysis, the same association was found in overall Caucasian (T versus $\mathrm{C}, \mathrm{OR}=1.16,95 \%$ CI 1.08-1.24) and Chinese populations (TT versus CC, OR=1.23, 95\% CI 1.06-1.57). No associations were detected between GNB3-C825T and the risk of EH overall in Asian and Japanese people.

Conclusions: Meta-analysis results suggest that the GNB3-C825T polymorphism is associated with risk of EH in the overall population, the Caucasians and the Chinese. The effect of the variants on the expression levels and the possible functional role of the variants in EH should be addressed in further studies.
\end{abstract}

Key words: GTP-Binding Proteins, Polymorphism, Genetic hypertension, Meta-Analysis

\section{INTRODUCTION}

Essential hypertension (EH), a complex disease which accounts for $\sim 95 \%$ of hypertensive cases, is an increasingly serious worldwide public-health challenge and is generally considered as a paradigmatic multi-factorial disease that is determined by a combination of genetic factors, environmental stimuli and their interaction (O'Shaughnessy, 2001). It was estimated that $20-60 \%$ of the inter-individual variation in blood pressure (BP) is genetically controlled (Kurtz and Spence, 1993). Accordingly, the discovery of many potential hypertension-susceptibility genes has allowed for a better understanding of the disease etiology. Candidate polymorphisms of the genes involved in the pathways of $\mathrm{Na}^{+} / \mathrm{H}^{+}$exchange, the renin-angiotensinaldosterone system and the autonomic nervous system such as G-protein $\beta 3$-subunit (GNB3)-C825T, angiotensin-converting enzyme insertion/deletion, and $\beta 2$-adrenergic receptor A46G have been investigated in different ethnic populations (Puddu et al., 2007).

G-proteins are hetero-trimers composed of $\alpha, \beta$, and $\gamma$ subunits, which act as switches for signal transduction from the extracellular space into the cell via their interaction with G-protein-coupled receptors. The $\beta$-subunit plays an important role in regulation of the $\alpha$-subunit and several signal transduction receptors and effectors (Downes and Gantam, 1999). A previous study demonstrated that enhanced signal transduction and cell proliferation were abnormalities in a certain group of patients with $\mathrm{EH}$ and revealed that enhanced $G$ protein activation led to this common disorder (Siffert et al., 1995). The GNB3 gene is one of the five genes coding for a G-protein $\beta$-subunit that have been identified in the human genome (Elefsinioti et al., 2004). One widelystudied polymorphism of the GNB3 gene is the C825T polymorphism, which consists of a substitution of $\mathrm{C}$ by $\mathrm{T}$ at position 825 in exon 10. Siffert et al. (1998) first found that the GNB3-825T allele was associated with EH. Since then, many researchers have studied the relationship between the GNB3C825T polymorphism and $\mathrm{EH}$ in different populations with controversial results (Snapir et al., 2001; Huang et al., 2003; Potoczna et al., 2004). To estimate fully and comprehensively the association between this gene polymorphism and EH risk across different ethnic populations we conducted an updated meta-analysis, including more studies in the Asian population than the meta-analysis of Bagos et al. carried out in 2007, to derive a more precise estimation of the association.

\section{MATERIALS AND METHODS}

Literature search

To search for all the studies that examined the association of the GNB3-C825T polymorphism with essential hypertension risk we conducted a computerized literature search from PubMed, Embase, CBM (China Biological Medicine Database), Wanfang 
and VIP databases, using the following keywords and subject terms: (hypertension or blood pressure or essential hypertension) AND (GNB3-C825T or G-protein beta3) AND (allele or genotype or polymorphism or variant or variation). The full text of the retrieved articles was scrutinized to inspect whether data on the topic of interest were included. We systematically searched eligible studies reported before March 1, 2013.

Eligible publications had to be written in either Chinese or English. The references of all retrieved articles were also screened. To prevent data duplication, when a report overlapped with another study, only the more detailed study was included. If an article reported results on different ethnic sub-populations, each sub-population was treated as a separate study.

\section{Inclusion/exclusion criteria}

Studies included in the meta-analysis had to meet all the following criteria: (1) the evaluation of the relationship between the GNB3-C825T polymorphism and essential hypertension; (2) the use of case-control study design or cross-sectional study design; (3) the available genotype/allele frequency of the GNB3-C825T allele between cases and controls; (4) all subjects were well ethnicity-matched; (5) hypertension was defined as systolic BP equal to or above $140 \mathrm{mmHg}$ or diastolic BP equal to or above $90 \mathrm{mmHg}$ or treatment with antihypertensive medication; however, studies evaluating secondary hypertension or other types of monogenic hypertension were excluded from the present investigation. If the genotype frequency was not reported, we contacted the original authors by e-mail to obtain the missing data.

\section{Data extraction}

To minimize the selection bias, the data were independently gathered in duplicate by two investigators on the basis of a standard protocol. The data extracted from the studies included such details as the first author, the year of publication, study population (region, ethnicity and sex), total number of cases and controls and genotype information. The excluded studies were comprised of studies of poor research quality, providing little or insufficient data, violating the inclusion criteria, and repeated publications. If the same research result appeared in different articles, the result was only adopted once in the present meta-analysis. If there was discrepancy between them, it was settled by discussion until a consensus was reached.

\section{Statistical Analysis}

As case-control or cross-sectional studies were used, odds ratios (ORs) corresponding to a 95\% confidence interval (CI) were implemented to assess the intensity of the association between the GNB3-C825T polymorphism and EH; the ORs were calculated according to the method described by Woolf (WOOLF 1955). We examined the contrast of the T vs. C, TT vs. $\mathrm{CC}, \mathrm{TC}$ vs. CC, and also examined the dominant genetic model $\mathrm{TT}+\mathrm{TC}$ vs. CC and the recessive model TT vs. TC+CC.

We applied two models of meta-analysis for dichotomous outcomes in Review-Manager 5.0 software (The Cochrane Collaboration, Oxford, UK): the fixed-effects model and the random-effects model. When there was inter-study heterogeneity a pooled OR was estimated by the random-effects model (DerSimonian and Laird's method) (DerSimonian and Laird, 1986); otherwise the fixed-effects model (Mantel-Haenszel method) was used (Mantel and Haenszel, 1959). The fixed-effects model assumes homogeneity among study estimates and is used when there is no evidence for heterogeneity. Conversely, when heterogeneity exists a random-effects model is usually more appropriate because it takes into account the inter-study variability. We used a $\chi^{2}$-based $Q$ statistic to assess the interstudy heterogeneity (Lau et al.,1997), which is considered to be significant for $P<0.10$ because of the low power of the statistic, as well as the $I^{2}$ statistic for estimation of inconsistency in metaanalysis (Trikalinos et al., 2006). Heterogeneity was assessed by the $I^{2}$ statistic, which was documented for the percentage of the observed inter-study variability due to heterogeneity rather than chance; it ranges from 0 to $100 \%$, where a value of $0 \%$ indicates no observed heterogeneity, and larger values indicate an increasing degree of heterogeneity (roughly suggested cut-off points include: $I^{2}=0-25 \%$, no heterogeneity; $I^{2}=25-50 \%$, moderate heterogeneity; $I^{2}=50-75 \%$, large heterogeneity; $I^{2}=75-100 \%$, extreme heterogeneity (Higgins et al., 2003). The fixed-effects model (if $P \geq 0.10$ ) or the random-effects model (if $P<0.10$ ) was used to pool the results. The significance of the pooled ORs was determined by the Z-test, and $P<0.05$ was considered significantly different.

Sensitivity analyses were conducted by deleting a single study each time involved in the meta-analysis to identify the potential influence of the individual dataset on the pooled ORs.

A funnel plot was used to estimate the potential publication bias. The asymmetry of the funnel plot was assessed by Egger's linear regression test (Song and Gilbody, 1998).

\section{RESULTS}

Studies included in the meta-analysis

A total of forty relevant studies concerning the association between GNB3-C825T and the risk of EH were identified. These studies involved 16,518 patients and 20,284 controls, containing the studies of fourteen Caucasian populations, twenty-four Asian populations and two African-American populations. Because the sample population in the AfricanAmerican group was inadequate, ethnicity-specific metaanalysis was conducted on Caucasian and Asian populations. In the subgroup analysis, eight studies in Japanese populations and fifteen studies in Chinese populations were included in Asian-specific groups. Among those forty studies there were four that contained information about distinct independent populations and thus they were considered as different studies that should be counted twice (Brand et al., 1999; Kunugi et al., 2002; Ishikawa et al., 2000; Dai et al., 2002 . Out of all those studies, we found that the control groups were in Hardy-Weinberg equilibrium (HWE) except for four studies (Benjafield et al.,1998; Andersen et al., 2006; Yamamoto et al., 2004; Suwazono et al., 2004).The main characteristics of included studies are listed in Table 1.

\section{Frequency of the GNB3-825T Allele in Different Ethnic Groups}

There was no significant heterogeneity among the fourteen Caucasian population studies for a mixed company $\left(\chi^{2}=19.47\right.$, 
TABLE 1

Characteristics of the studies included in meta-analysis

\begin{tabular}{|c|c|c|c|c|c|c|c|c|c|c|c|c|}
\hline \multirow{3}{*}{ Study } & \multirow{3}{*}{ Year } & \multirow{3}{*}{ Region } & \multirow{3}{*}{ Ethnicity } & \multirow{3}{*}{ Sex } & \multirow{3}{*}{$\begin{array}{l}\text { Sample Size } \\
\text { Control/Case }\end{array}$} & \multicolumn{6}{|c|}{ Genotype Frequency } & \multirow{3}{*}{ HWE } \\
\hline & & & & & & \multicolumn{2}{|c|}{ Control } & \multicolumn{4}{|c|}{ EH patients } & \\
\hline & & & & & & $\mathrm{CC}$ & CT & TT & $\mathrm{CC}$ & CT & TT & \\
\hline Siffert et al. & 1998 & Germany & $\mathrm{C}$ & ALL & $427 / 426$ & 239 & 162 & 26 & 200 & 187 & 39 & Yes \\
\hline Benjafield et al. & 1998 & Australia & $\mathrm{C}$ & ALL & $189 / 110$ & 101 & 82 & 6 & 27 & 71 & 12 & No \\
\hline Brand et al. & 1999 & France & $\mathrm{C}$ & ALL & $308 / 681$ & 148 & 127 & 33 & 292 & 302 & 87 & Yes \\
\hline Brand et al. & 1999 & Ireland & $\mathrm{C}$ & M & $159 / 206$ & 78 & 70 & 11 & 98 & 92 & 16 & Yes \\
\hline Beige et al. & 1999 & Germany & $\mathrm{C}$ & ALL & $1000 / 476$ & 514 & 412 & 74 & 201 & 224 & 51 & Yes \\
\hline $\begin{array}{l}\text { Hengstenberg } \\
\text { et al. }\end{array}$ & 2000 & Germany & $\mathrm{C}$ & ALL & $1126 / 926$ & 526 & 485 & 115 & 407 & 407 & 112 & Yes \\
\hline Hengstenberg et al. & 2000 & Germany & $\mathrm{C}$ & ALL & $383 / 223$ & 179 & 165 & 39 & 99 & 101 & 23 & Yes \\
\hline Buchmayer et al. & 2000 & Australia & $\mathrm{C}$ & ALL & $174 / 174$ & 72 & 85 & 17 & 85 & 70 & 19 & Yes \\
\hline Zychma et al. & 2000 & Poland & $\mathrm{C}$ & ALL & $157 / 245$ & 68 & 77 & 12 & 109 & 144 & 22 & Yes \\
\hline Potoczna et al. & 2004 & Switzerland & $\mathrm{C}$ & ALL & $112 / 192$ & 57 & 40 & 15 & 86 & 82 & 24 & Yes \\
\hline Martin et al. & 2005 & Spain & $\mathrm{C}$ & ALL & $78 / 76$ & 29 & 36 & 13 & 25 & 42 & 9 & Yes \\
\hline Mahmood et al. & 2005 & United Arabian Emirates & $\mathrm{C}$ & ALL & $211 / 145$ & 43 & 118 & 50 & 25 & 81 & 39 & Yes \\
\hline Andersen et al. & 2005 & Denmak & $\mathrm{C}$ & ALL & $4193 / 3139$ & 2022 & 1744 & 427 & 1545 & 1288 & 306 & No \\
\hline Kedzierska et al. & 2006 & Poland & $\mathrm{C}$ & M & $18 / 26$ & 15 & 2 & 1 & 9 & 12 & 5 & Yes \\
\hline Alioğlu et al. & 2008 & Turkish & $\mathrm{C}$ & ALL & $82 / 209$ & 27 & 40 & 15 & 37 & 124 & 48 & Yes \\
\hline Cabadak et al. & 2011 & Turkish & $\mathrm{C}$ & ALL & $106 / 101$ & 47 & 37 & 22 & 35 & 31 & 35 & Yes \\
\hline Kato et al & 1998 & Japan & $\mathrm{A}$ & ALL & $515 / 718$ & 128 & 263 & 124 & 187 & 359 & 172 & Yes \\
\hline Kario et al. & 1999 & Japan & A & ALL & $106 / 161$ & 22 & 51 & 33 & 29 & 93 & 39 & Yes \\
\hline Ishikawa et al. & 2000 & Japan & A & ALL & $422 / 304$ & 96 & 204 & 122 & 67 & 161 & 76 & Yes \\
\hline Ishikawa et al. & 2000 & Japan & A & ALL & $165 / 181$ & 37 & 85 & 43 & 43 & 90 & 48 & Yes \\
\hline Tsai et al. & 2000 & Taiwan, China & A & ALL & $199 / 302$ & 43 & 96 & 60 & 57 & 149 & 96 & Yes \\
\hline You et al & 2000 & China & A & ALL & $100 / 98$ & 31 & 52 & 27 & 25 & 47 & 26 & Yes \\
\hline Tozawa et al. & 2001 & Japan & $\mathrm{A}$ & ALL & $180 / 179$ & 39 & 82 & 59 & 32 & 68 & 79 & Yes \\
\hline Dai et al. & 2002 & China & $\mathrm{A}$ & ALL & $257 / 133$ & 70 & 127 & 60 & 28 & 73 & 32 & Yes \\
\hline Dai et al. & 2002 & China & $\mathrm{A}$ & ALL & $110 / 98$ & 31 & 52 & 27 & 25 & 47 & 26 & Yes \\
\hline Wang et al. & 2003 & China & A & ALL & $140 / 408$ & 39 & 66 & 35 & 131 & 182 & 95 & Yes \\
\hline Izawa et al. & 2003 & Japan & A & M & $533 / 574$ & 159 & 261 & 113 & 138 & 291 & 145 & Yes \\
\hline Huang et al. & 2003 & China & A & ALL & $580 / 585$ & 126 & 303 & 151 & 134 & 290 & 161 & Yes \\
\hline Tan et al. & 2003 & China & A & ALL & $112 / 112$ & 66 & 40 & 6 & 38 & 60 & 14 & Yes \\
\hline Yamamoto et al. & 2004 & Japan & A & ALL & $540 / 266$ & 162 & 239 & 139 & 70 & 120 & 76 & No \\
\hline Wang et al. & 2004 & China & A & ALL & $244 / 290$ & 67 & 119 & 58 & 82 & 144 & 64 & Yes \\
\hline Suwazono et al. & 2004 & Japan & $\mathrm{A}$ & ALL & $2289 / 332$ & 574 & 1216 & 499 & 78 & 171 & 83 & No \\
\hline Shioji et al. & 2004 & Japan & $\mathrm{A}$ & ALL & $1105 / 775$ & 287 & 536 & 282 & 177 & 385 & 213 & Yes \\
\hline Li et al. & 2005 & China & A & ALL & $503 / 501$ & 137 & 259 & 107 & 142 & 256 & 103 & Yes \\
\hline Zhang et al. & 2005 & China & $\mathrm{A}$ & ALL & $150 / 110$ & 51 & 72 & 27 & 32 & 52 & 27 & Yes \\
\hline Dong et al. & 2006 & China & $\mathrm{A}$ & ALL & $87 / 97$ & 27 & 46 & 14 & 25 & 47 & 25 & Yes \\
\hline Li et al. & 2006 & China & A & ALL & $151 / 310$ & 42 & 70 & 39 & 89 & 161 & 60 & Yes \\
\hline Zhang et al. & 2006 & China & A & ALL & $100 / 100$ & 32 & 53 & 15 & 19 & 46 & 35 & Yes \\
\hline Bae et al. & 2007 & Korea & A & ALL & $924 / 688$ & 217 & 469 & 238 & 193 & 139 & 175 & Yes \\
\hline Huang et al. & 2007 & China & $\mathrm{A}$ & ALL & $495 / 256$ & 104 & 262 & 129 & 51 & 133 & 72 & Yes \\
\hline Gai et al. & 2007 & China & $\mathrm{A}$ & ALL & $197 / 136$ & 54 & 95 & 48 & 31 & 73 & 32 & Yes \\
\hline Zhao et al. & 2009 & China & $\mathrm{A}$ & ALL & $293 / 331$ & 52 & 137 & 104 & 117 & 179 & 35 & Yes \\
\hline Nejatizadeh et al. & 2011 & Iran & A & ALL & $345 / 449$ & 192 & 144 & 9 & 185 & 211 & 53 & Yes \\
\hline Dong et al. & 1999 & United Kingdom & African & ALL & $243 / 185$ & 14 & 83 & 146 & 3 & 61 & 121 & Yes \\
\hline Larson et al. & 2000 & United States of America & African & ALL & $432 / 472$ & 25 & 170 & 237 & 29 & 190 & 253 & Yes \\
\hline
\end{tabular}

HWE: Hardy-Weinberg equilibrium. 
$\mathrm{df}=15, P=0.21)$. The pooled GNB3-825T allele frequency using the fixed-effects model was $37.75 \%$ (95\% CI: 35.39-39.14\%).

The pooled GNB3-825T frequencies were $48.37 \%(95 \%$ CI: 46.94-52.27\% ) for Asians $\left(\chi^{2}=27.63, P<0.001\right.$; randomeffects model) and $76.28 \%$ (95\% CI: 71.03-82.46\%) for AfricanAmericans.
Results of Meta-analysis

In the meta-analysis of all involved studies, the $Q$ test showed heterogeneity in the 40 studies - we therefore used the random effects model to calculate the combined effects in the following genetic models. The OR (95\% CI) values (Fig. 1) were: T versus C: 1.09 (1.04-1.19) $P=0.012$; TT versus CC: 1.02 (0.88-1.26)

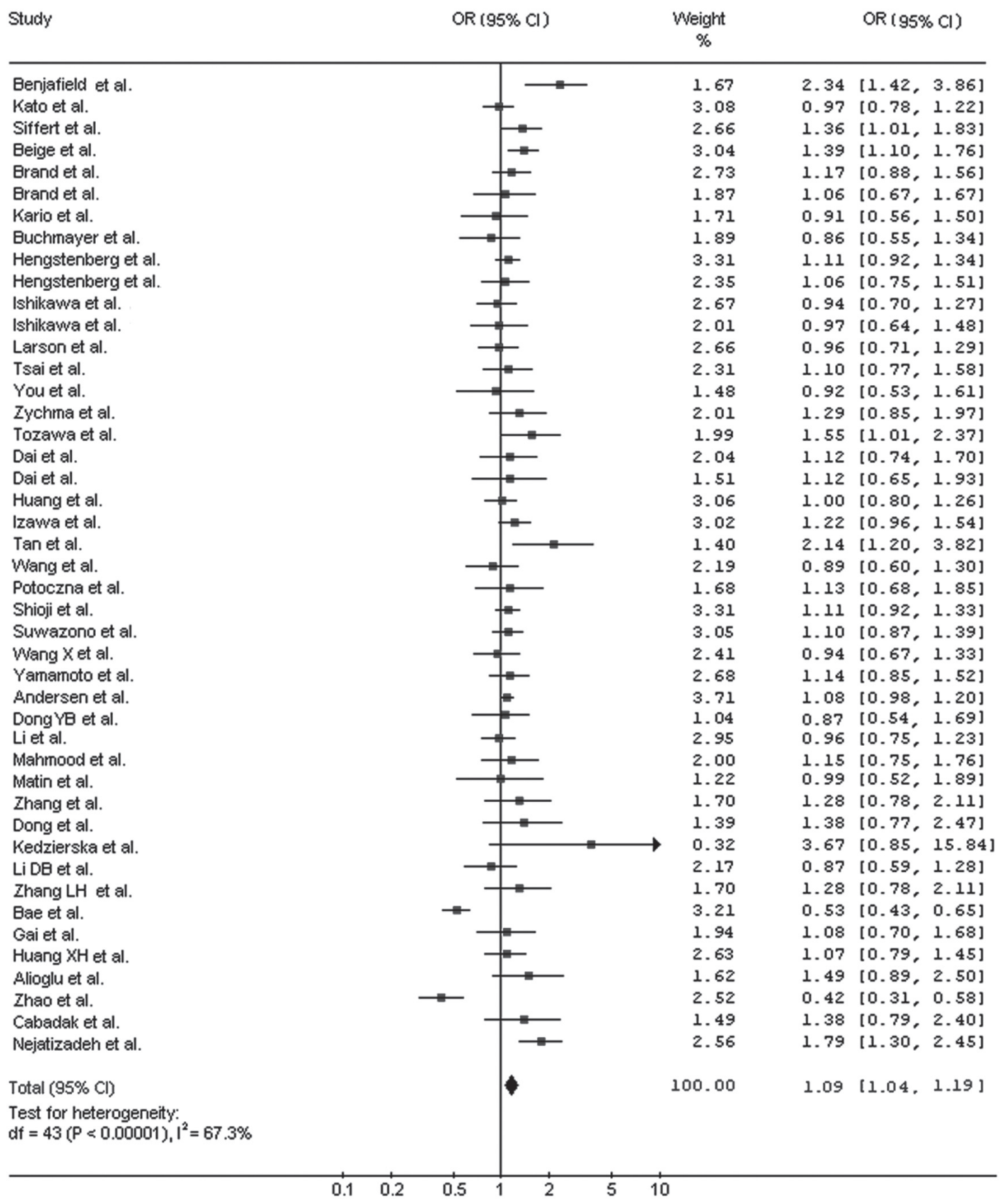

Figure 1: Pooled OR (T versus C) and $95 \% \mathrm{Cl}$ of individual studies and pooled data for the association between polymorphism of GNB3 C825T and EH in the overall population 
$P=0.005$; TC versus CC: $1.11(0.72-1.54) P=0.132$. However, no significant association was identified in the dominant model or in the recessive model (Table 2). Heterogeneity among studies was identified in all the comparisons ( $P$ for heterogeneity $Q$ test $<0.1$ ). Furthermore, the $I^{2}$ statistics suggested the existence of moderate heterogeneity for all comparisons in all studies. Therefore, a sub-group analysis of the studies by ethnicity grouping was suggested.

We found a significant association when all Caucasian population studies were pooled with the fixed-effects model for $\mathrm{T}$ versus $\mathrm{C}(\mathrm{OR}=1.16,95 \%$ CI 1.08-1.24; $P=0.216$ for heterogeneity, Fig. 2), TT+TC versus $\mathrm{CC}(\mathrm{OR}=1.33,95 \% \mathrm{CI}$ 1.13-1.56; $P=0.324$ for heterogeneity), TT versus TC + CC (OR=1.13, 95\% CI 1.02-1.20; $P=0.152$ for heterogeneity). The same association was found in the Chinese population when all studies were pooled with the random-effects model for TT vs. CC $(\mathrm{OR}=1.23,95 \%$ CI 1.06-1.57; $P<0.001$ for heterogeneity, Fig. 3). No associations were detected between GNB3-C825T and the risk of EH in Asians or the Japanese (Table 2).
Sensitivity Analysis

We removed the studies by Benjafield AV et al. (in the Caucasian population) and Yamamoto $M$ et al. (in the Asian population) in the meta-analysis, since the genotype distribution in the control groups of the study deviated slightly from HWE. We found that the corresponding pooled ORs were not substantially altered (Table 3), which indicated the reliability of our results.

\section{Publication Bias}

Begg's test and a funnel plot were performed to access the publication bias of the studies. In this study there was no significant publication bias for GNB3-C825T polymorphism (T versus $C$ : overall population, $P=0.106$; Caucasian population, $P=0.472$; Asian population, $P=0.645$ ). The funnel plot showed a symmetrical distribution of the studies (funnel plot of GNB3-

TABLE 2

The results of meta-analysis between GNB3-C825T polymorphism and EH

\begin{tabular}{|c|c|c|c|c|c|c|}
\hline \multirow{2}{*}{ Groups } & \multirow{2}{*}{ Genetic model } & \multirow{2}{*}{$\begin{array}{l}\text { Sample size } \\
\text { Control/Case }\end{array}$} & \multicolumn{2}{|c|}{ Test of heterogeneity } & \multirow{2}{*}{ OR(95\% CI) } & \multirow{2}{*}{$\begin{array}{c}Z(P) \text { value for } \\
\text { overall effect } \\
\text { test }\end{array}$} \\
\hline & & & $P$ & $I^{2}(\%)$ & & \\
\hline \multirow[t]{5}{*}{ Overall } & T vs.C & $20,284 / 16,518$ & $<0.001$ & 67.3 & $1.09(1.04-1.19)$ & $1.91(0.012)$ \\
\hline & TT vs. CC & & 0.003 & 34.8 & $1.02(0.88-1.26)$ & $2.13(0.005)$ \\
\hline & TC vs. CC & & 0.053 & 32.9 & $1.10(0.72-1.54)$ & $2.21(0.132)$ \\
\hline & $\mathrm{TT}+\mathrm{TC}$ vs. CC & & 0.103 & 25.1 & $1.04(0.79-1.34)$ & $1.96(0.038)$ \\
\hline & TT vs. TC+CC & & $<0.001$ & 51.4 & $1.01(0.84-1.24)$ & $1.90(0.024)$ \\
\hline \multirow[t]{5}{*}{ Caucasian-overall } & T vs.C & $8723 / 7355$ & 0.216 & 21.2 & $1.16(1.08-1.24)$ & $4.20(<0.001)$ \\
\hline & TT vs. CC & & 0.135 & 39.8 & $1.02(0.75-1.37)$ & $2.82(0.084)$ \\
\hline & TC vs. CC & & 0.118 & 26.4 & $1.01(0.84-1.24)$ & $3.37(0.139)$ \\
\hline & $\mathrm{TT}+\mathrm{TC}$ vs. $\mathrm{CC}$ & & 0.324 & 12.6 & $1.33(1.13-1.56)$ & $3.40(0.007)$ \\
\hline & TT vs. TC+CC & & 0.152 & 27.6 & $1.13(1.02-1.25)$ & $2.29(0.026)$ \\
\hline \multirow[t]{5}{*}{ Asian-overall } & T vs.C & $10,886 / 8,504$ & $<0.001$ & 64.2 & $0.99(0.93-1.05)$ & $0.30(0.562)$ \\
\hline & TT vs. CC & & 0.093 & 53.6 & $0.86(0.67-1.19)$ & $1.58(0.081)$ \\
\hline & TC vs. CC & & 0.262 & 37.1 & $1.14(0.84-1.55)$ & $0.62(0.006)$ \\
\hline & $\mathrm{TT}+\mathrm{TC}$ vs. CC & & 0.053 & 49.5 & $1.16(0.89-1.51)$ & $1.08(0.279)$ \\
\hline & TT vs. TC $+\mathrm{CC}$ & & 0.006 & 44.8 & $0.94(0.72-1.21)$ & $0.49(0.184)$ \\
\hline \multirow[t]{5}{*}{ Japanese-overall } & T vs.C & $5849 / 3490$ & 0.62 & 0.00 & $1.09(1.00-1.19)$ & $1.87(0.059)$ \\
\hline & TT vs. CC & & 0.271 & 23.4 & $1.01(0.76-1.38)$ & $1.48(0.259)$ \\
\hline & TC vs. CC & & 0.324 & 13.7 & $0.77(0.56-1.33)$ & $0.73(0.008)$ \\
\hline & $\mathrm{TT}+\mathrm{TC}$ vs. CC & & $<0.001$ & 68.6 & $1.12(0.81-1.55)$ & $0.67(0.531)$ \\
\hline & TT vs. TC $+\mathrm{CC}$ & & 0.236 & 24.2 & $1.10(0.99-1.21)$ & $1.74(0.044)$ \\
\hline \multirow[t]{5}{*}{ Chinese-overall } & T vs.C & $3768 / 3877$ & $<0.001$ & 57.4 & $1.12(0.86-1.46)$ & $0.67(0.421)$ \\
\hline & TT vs. CC & & $<0.001$ & 64.1 & $1.23(1.06-1.57)$ & $1.26(0.032)$ \\
\hline & TC vs. CC & & $<0.001$ & 70.3 & $0.84(0.62-1.27)$ & $1.35(0.102)$ \\
\hline & $\mathrm{TT}+\mathrm{TC}$ vs. $\mathrm{CC}$ & & $<0.001$ & 52.9 & $1.09(0.89-1.34)$ & $0.29(0.837)$ \\
\hline & TT vs. TC+CC & & $<0.001$ & 62.8 & $0.96(0.65-1.42)$ & $0.84(0.328)$ \\
\hline
\end{tabular}


$825 \mathrm{~T}$ versus $\mathrm{C}$ and susceptibility of $\mathrm{EH}$ in overall population is shown in Fig. 4).

\section{DISCUSSION}

Our results indicated that the prevalence of the GNB3-825T allele varied from $37.75-76.28 \%$ in different ethnic groups, the lowest being demonstrated for Caucasians and the highest for AfricanAmericans. Furthermore, meta-analysis results showed that an association existed between the GNB3-C825T allele frequency and risk of $\mathrm{EH}$ in the overall population ( $\mathrm{T}$ versus $\mathrm{C}, \mathrm{OR}=1.09$, 95\% CI 1.04-1.19), and the Caucasian ( $\mathrm{T}$ versus $\mathrm{C}$, $\mathrm{OR}=1.16$, 95\% CI 1.08-1.24; TT+TC versus CC, OR=1.33, 95\% CI 1.13-1.56; $\mathrm{TT}$ versus $\mathrm{TC}+\mathrm{CC}, \mathrm{OR}=1.13,95 \% \mathrm{CI} 1.02-1.20)$ and Chinese populations (TT vs. CC, OR=1.23, 95\% CI 1.06-1.57). Conversely, no associations were detected in Asian or Japanese people.

G-proteins comprise a family of ubiquitously distributed signal-transduction proteins. Most membrane receptors rely on heterotrimeric G-proteins to activate or inhibit intracellular signaling cascades. G-proteins are influenced by hormones

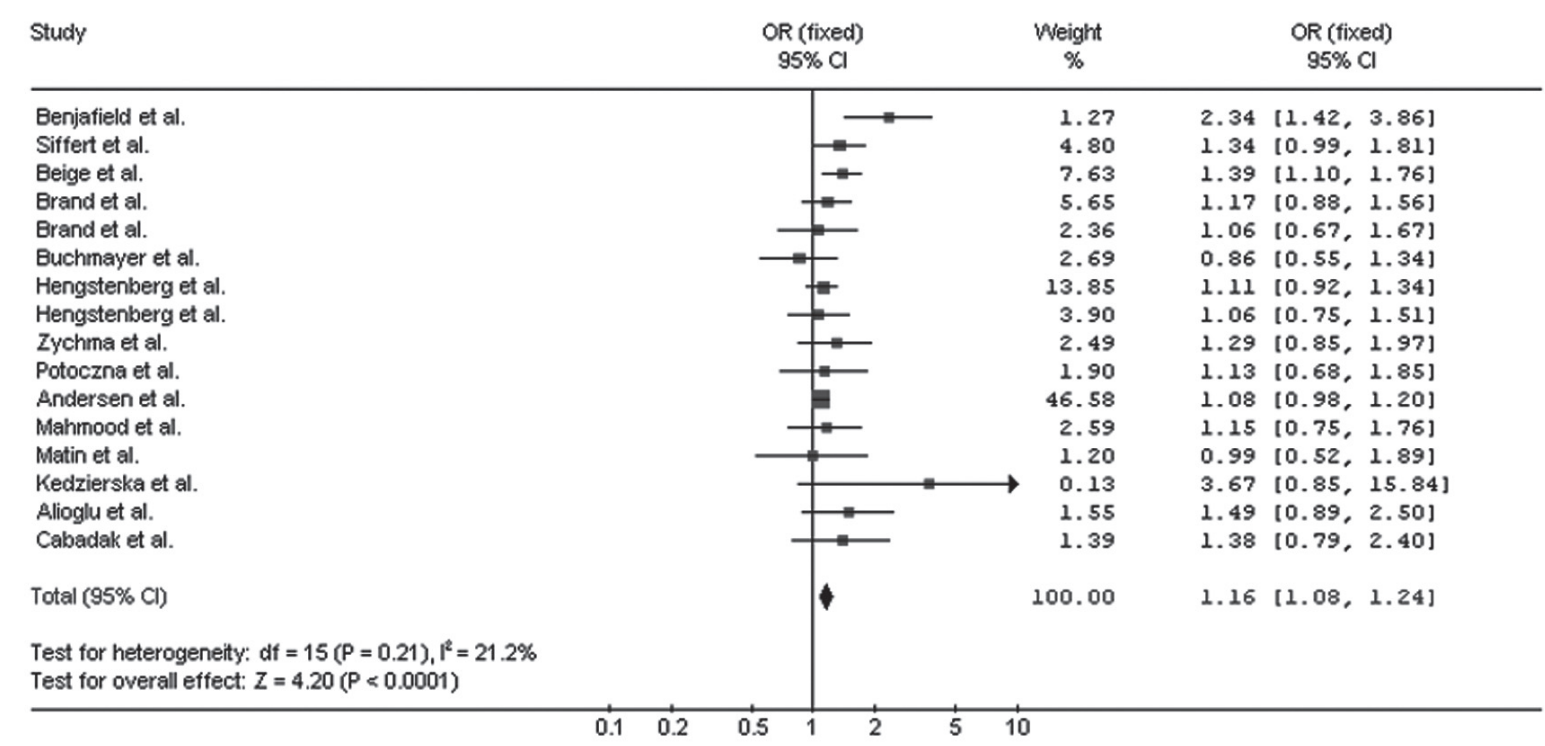

Figure 2: Pooled OR (T versus $\mathrm{C}$ ) and $95 \% \mathrm{Cl}$ of individual studies and pooled data for the association between polymorphism of GNB3C825T and EH in Caucasian population

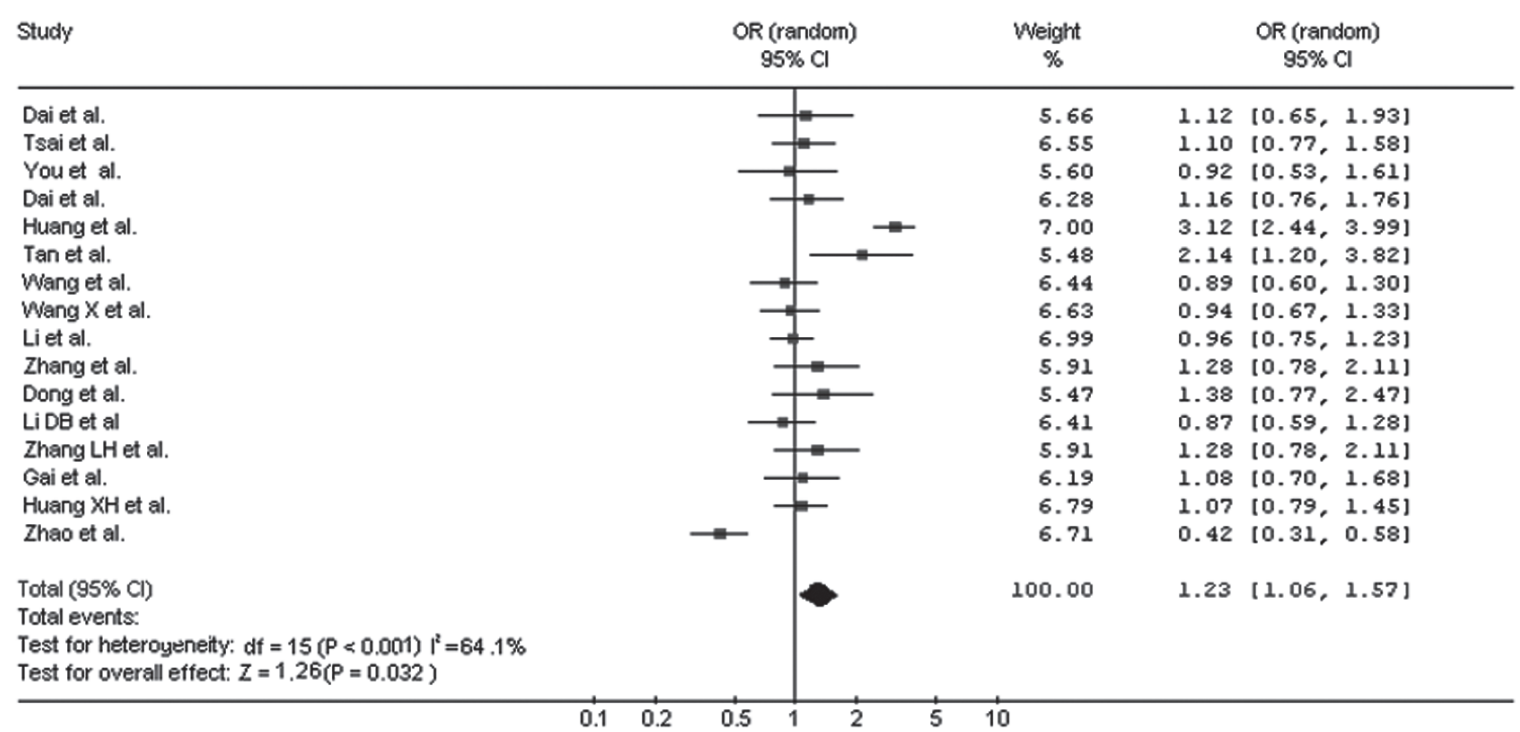

Figure 3: Pooled OR (TT versus CC) and $95 \% \mathrm{Cl}$ of individual studies and pooled data for the association between polymorphism of GNB3-C825T and EH in Chinese population. 
TABLE 3

Main results of the pooled $O R$ in sensitivity analysis

\begin{tabular}{|c|c|c|c|c|c|c|}
\hline \multirow{2}{*}{ Groups } & \multirow{2}{*}{ Genetic model } & \multirow{2}{*}{$\begin{array}{l}\text { Sample Size } \\
\text { Control/Case }\end{array}$} & \multicolumn{2}{|c|}{ Test of heterogeneity } & \multirow{2}{*}{ OR $(95 \% \mathrm{CI})$} & \multirow{2}{*}{$\begin{array}{c}Z(P) \text { value for } \\
\text { overall effect } \\
\text { test }\end{array}$} \\
\hline & & & $P$ & $I^{2}$ & & \\
\hline \multirow[t]{5}{*}{ Caucasian-overall } & T vs.C & $8,544 / 7,245$ & 0.211 & 20.9 & $1.17(1.07-1.25)$ & $4.18(<0.001)$ \\
\hline & TT vs. CC & & 0.134 & 39.3 & $1.02(0.75-1.37)$ & $2.81(0.084)$ \\
\hline & TC vs. CC & & 0.137 & 27.0 & $1.01(0.84-1.24)$ & $3.41(0.138)$ \\
\hline & TT+TC vs. CC & & 0.175 & 13.4 & $1.33(1.12-1.56)$ & $3.42(0.007)$ \\
\hline & TT vs. $\mathrm{TC}+\mathrm{CC}$ & & 0.184 & 25.3 & $1.13(1.02-1.25)$ & $2.28(0.031)$ \\
\hline \multirow[t]{5}{*}{ Asian-overall } & T vs.C & $10,336 / 8,238$ & $<0.001$ & 64.2 & $0.97(0.92-1.05)$ & $0.28(0.558)$ \\
\hline & TT vs. CC & & 0.089 & 52.7 & $0.86(0.67-1.10)$ & $1.61(0.089)$ \\
\hline & TC vs. CC & & 0.264 & 36.8 & $1.14(0.82-1.56)$ & $0.62(0.025)$ \\
\hline & TT+TC vs. CC & & 0.053 & 50.1 & $1.15(0.89-1.51)$ & $1.06(0.264)$ \\
\hline & TT vs. $\mathrm{TC}+\mathrm{CC}$ & & 0.005 & 43.7 & $0.93(0.72-1.21)$ & $0.51(0.182)$ \\
\hline
\end{tabular}

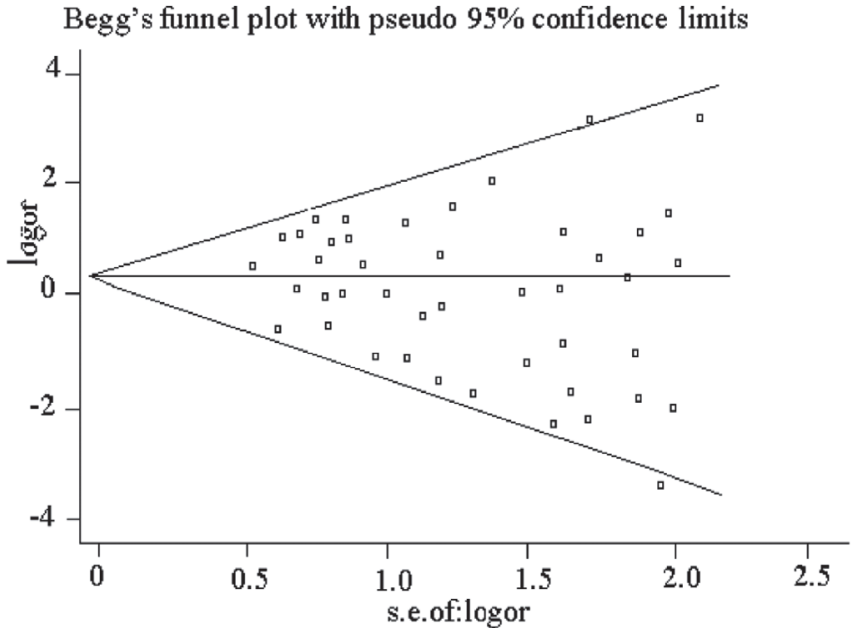

Figure 4: Funnel plot for detecting publication bias among all studies for allele comparison (GNB3-825T versus $C$ ) in the overall population. Logor (y axis) the log of OR,s.e. of logor (x axis) the standard error of lor(OR). OR: odds ratio.

and neurotransmitters and act to regulate blood pressure. Polymorphisms of the GNB3 gene have received considerable attention as candidate genes for EH. The GNB3-C825T allele was demonstrated to lack 41 amino acids in the $\beta 3$ subunit of trimeric G-proteins (Siffert et al., 1998). This allele has also been associated with enhanced G-protein signaling (Siffert et al., 1998; Sun et al., 2005), presumably through abnormal stability or functional interactions of the shortened G-proteins.

In recent years many studies have reported a correlation between GNB3-C825T and EH in Caucasian, African, South American and Asian populations. Our analysis showed that the GNB3-C825T allele was associated with EH in the overall population, which is in agreement with the results of a previous multi-ethnic population meta-analysis (Bagos et al., 2007). These authors reported that TT versus CC + CT: $\mathrm{OR}=1.08,95 \% \mathrm{CI}: 1.01-1.15, \mathrm{P}<0.001$ and $\mathrm{TT}+\mathrm{CT}$ versus
CC: $\mathrm{OR}=1.17$, 95\% CI: 1.06-1.29, $\mathrm{P}<0.001$. Further subgroup analysis led to a similar result, i.e., significant associations from studies in the Caucasian population and no associations from studies in Asians. However, we did observe that the GNB3-825T allele (TT vs. CC, OR=1.23, 95\% CI 1.06-1.57) was a risk factor for $\mathrm{EH}$ in Chinese people. Our studies of the Chinese population involving GNB3-C825T and EH risk include not only the mainland investigations but also Taiwanese ones.

In addition, we calculated the average frequency of the $\mathrm{T}$ allele in different ethnic people, which was lowest in Caucasians, intermediate in Asian, and the highest in Africans. Siffert et al. analyzed the distribution frequencies of GNB3-C825T from a German cohort, and Chinese and African populations, and found that $\mathrm{T}$ allele frequencies differed significantly among different ethnic groups and were the lowest in Germans (31.9\%), intermediate in Chinese $(47.7 \%)$ and highest in Africans (81.4-84.1\%) (Siffert et al., 1998). The different genotypic frequencies of GNB3-825T allele might influence the phenotypes related to hypertension such as salt sensitivity in different ethnic populations (Franco et al., 2006), which may contribute to different correlations between Chinese and other populations. It is worth noting that the number of studies from the African population was much lower than for other races. More studies from African people are needed to re-estimate the frequency.

Some limitations of this meta-analysis should be discussed. First, this meta-analysis focused only on papers published in the English and Chinese languages and the ones that reported in other languages may bias the present results, even though publication bias was not detected with Begg's test. Additionally, there may be other eligible studies that were not published and indexed by electronic databases. Third, significant between-study heterogeneity was observed. Although we used the random-effects model to pool ORs, it may affect the precision of results. Finally, lack of individual participants' data restricted the further adjustments by other co-variables such as smoking, body mass index, hyperlipidemia, etc. 


\section{CONCLUSIONS}

The results of the meta-analysis suggest that the GNB3$825 \mathrm{~T}$ allele is associated with increased risk of $\mathrm{EH}$ in the overall population, as well as the Caucasian and Chinese populations. The $\mathrm{T}$ allele frequency is the lowest in Caucasians, intermediate in Asians, and highest in Africans. The effect of the variants on the expression levels and the possible functional role of the variants of $\mathrm{EH}$ should be addressed in further studies.

\section{REFERENCES}

ALIOĞLU E, ERCAN E, TENGIZ I, YILDIZ A, ONSEL TÜRK U, SAYGI S, CAM FS, BERDELI A(2008) G protein beta3 subunit gene polymorphism in Turkish hypertensives. Anadolu Kardiyol Derg 8:331-335.

ANDERSEN G, OVERGAARD J, ALBRECHTSEN A, GLUMER C, BORCHJOHNSEN K, JØRGENSEN T, HANSEN T, PEDERSEN O(2006) Studies of the association of the GNB3 $825 \mathrm{C}>\mathrm{T}$ polymorphism with components of the metabolic syndrome in white Danes. Diabetologia 49:75-82.

BAE Y, PARK C, HAN J, HONG YJ, SONG HH, SHIN ES, LEE JE, HAN BG, JANG Y, SHIN DJ, YOON SK(2007) Interaction between GNB3 C825T and ACE I/D polymorphisms in essential hypertension in Koreans.J Hum Hypertens 21:159-166.

BAGOS PG, ELEFSINIOTI AL, NIKOLOPOULOS GK, HAMODRAKAS SJ(2007).The GNB3 C825T polymorphism and essential hypertension: a meta-analysis of 34 studies including 14,094 cases and 17,760 controls.J Hypertens 25:487-500.

BEIGE J, HOHENBLEICHER H, DISTLER A, SHARMA AM(1999) G-Protein beta3 subunit C825T variant and ambulatory blood pressure in essential hypertension. Hypertension 33:1049-1051.

BENJAFIELD AV, JEYASINGAM CL, NYHOLT DR, GRIFFITHS LR, MORRIS BJ(1998) G-protein beta3 subunit gene (GNB3) variant in causation of essential hypertension. Hypertension 32:1094-1097.

BRAND E, HERRMANN SM, NICAUD V, RUIDAVETS JB, EVANS A, ARVEILER D, LUC G, PLOUIN PF, TIRET L, CAMBIEN F(1999) The $825 \mathrm{C} / \mathrm{T}$ polymorphism of the G-protein subunit beta3 is not related to hypertension. Hypertension 33:1175-1178.

BUCHMAYER H, SUNDER-PLASSMANN G, HIRSCHL MM, KLETZMAYR J, WOISETSCHLÄGER C, LAGGNER AN, HÖRL WH, FÖDINGER M(2000) G-protein beta3 subunit gene (GNB3) polymorphism 825C-->T in patients with hypertensive crisis. Crit Care Med 28:3203-3206.

CABADAK H, ORUN O, NACAR C, DOGAN Y, GUNEYSEL O, FAK AS, KAN B(2011) The role of $G$ protein $\beta 3$ subunit polymorphisms C825T, C1429T, and G5177A in Turkish subjects with essential hypertension. Clin Exp Hypertens 33:202-208.

DAI SP, SHI JP, DING Q, WANG HL, DONG LY, SUN D, FANG K, ZHAO YY(2002) Polymorphism analysis of $825 \mathrm{C} / \mathrm{T}$ of the G-protein beta 3 subunit in high risk population of hypertension in the northeast China. Yi Chuan Xue Bao 29:294-298.

DERSIMONIAN R, LAIRD N(1986) Meta-analysis in clinical trials. Control Clin Trials 7:177-188.

DONG HY, LI QR, WANG Q, LUO ZG (2006) Association analysis between genetic polymorphism of ADD1 gene and GNB3 gene and essential hyper tension. South China J Cardiovasc Dis 12:258-261.

DONG Y, ZHU H, SAGNELLA GA, CARTER ND, COOK DG, CAPPUCCIO FP(1999). Association between the C825T polymorphism of the $\mathrm{G}$ protein beta3- subunit gene and hypertension in blacks. Hypertension34:1193-6.

DOWNES GB, GAUTAM N(1999) The G protein subunit gene families. Genomics 62:544-552.

ELEFSINIOTI AL, BAGOS PG, SPYROPOULOS IC, HAMODRAKAS SJ(2004). A database for $G$ proteins and their interaction with GPCRs. BMC Bioinformatics 5:208.

FRANCO V, OPARIL S(2006) Salt sensitivity, a determinant of blood pressure, cardiovascular disease and survival. J Am Coll Nutr 25:247S-255S

GAI XQ, SHI JP, ZHAO YY(2007) Multivariate analysis on the relationship between $\mathrm{G}$ protein beta3 subunit gene $825 \mathrm{C} / \mathrm{T}$ polymorphism and essential hypertension.Zhonghua Liu Xing Bing Xue Za Zhi 28:413-414.

HIGGINS JP, THOMPSON SG, DEEKS JJ, ALTMAN DG(2003) Measuring inconsistency in meta-analyses. BMJ 327:557-560.
HUANG $\mathrm{X}$, JU Z, SONG $\mathrm{Y}$, ZHANG $\mathrm{H}$, SUN $\mathrm{K}$, LU H, YANG Z, JOSE PA, ZHOU G, WANG M, WANG W, FENG S, HUI R(2003) Lack of association between the $G$ protein beta3 subunit gene and essential hypertension in Chinese: a case-control and a family-based study. J Mol Med (Berl) 81:729-35.

HUANG XH,SUN K,SONG Y(2007) Association of $\alpha$-adductin gene and G-protein-subuint gene with essential hypertension in Chinese .Natl Med J China 87:1682-1684.

ISHIKAWA K, IMAI Y, KATSUYA T, OHKUBO T, TSUII I, NAGAI K, TAKAMI S, NAKATA Y, SATOH H, HISAMICHI S, HIGAKI J, OGIHARA T(2000) Human G-protein beta3 subunit variant is associated with serum potassium and total cholesterol levels but not with blood pressure.Am J Hypertens13:140-145.

IZAWA H, YAMADA Y, OKADA T, TANAKA M, HIRAYAMA H, YOKOTA $M(2003)$ Prediction of genetic risk for hypertension.Hypertension 41:1035-1040.

KARIO K, FUJIWARA M, SONE Y, SAIKI K, HOSHIDE S, SHIMADA K, SCHWARTZ JE, MATSUO M (1999) G protein beta3 subunit gene variant, twenty-four-hour blood pressure, and hypertensive cerebrovascular disease in a Japanese population.Am J Hypertens 12:1159-1160.

KATO N, SUGIYAMA T, MORITA H, KURIHARA H, YAMORI Y, YAZAKI Y(1998).G protein beta3 subunit variant and essential hypertension in Japanese.Hypertension 32:935-938.

KEDZIERSKA K, CIECHANOWSKI $K$, SAFRANOW K, BOBER J, GOŁEMBIEWSKA E, KWIATKOWSKA E, KABAT-KOPERSKA J, OSTROWSKI M, ADLER G, CHLUBEK D(2006) GNB3 C825T and $A C E \mathrm{I} / \mathrm{D}$ polymorphisms on the sodium-proton exchanger and the prevalence of essential hypertension in males. Arch Med Res 37:150-157.

KURTZ TW, SPENCE MA(1993) Genetics of essential hypertension. Am J Med 94:77-84.

KUNUGI H, KATO T, FUKUDA R, TATSUMI M, SAKAI T, NANKO S(2002) Association study of C825T polymorphism of the G-protein b3 subunit gene with schizophrenia and mood disorders. J Neural Transm 109:213218.

LARSON N, HUTCHINSON R, BOERWINKLE E(2000) Lack of association of 3 functional gene variants with hypertension in African Americans. Hypertension 35:1297-1300.

LAU J, IOANNIDIS JP, SCHMID CH(1997) Quantitative synthesis in systematic reviews. Ann Intern Med 127:820-826.

LI B, GE D, WANG Y, ZHAO W, ZHOU X, GU D, CHEN R(2005) G protein beta 3 subunit gene variants and essential hypertension in the northern Chinese Han population. Ann Hum Genet 69:468-473.

LI DB, HUA Q, PI L (2006) Synergistic effects between eNOS gene G894T and GNB3 gene C825T polymorphisms in essential hypertension. J Cap Med Univ 27:480-4.

MAHMOOD MS, MIAN ZS, AFZAL A, FROSSARD PM(2005) G-protein beta-3 subunit gene $825 \mathrm{C}>\mathrm{T}$ dimorphism is associated with left ventricular hypertrophy but not essential hypertension. Med Sci Monit 11:CR6-9.

MANTEL N, HAENSZEL W(1959) Statistical aspects of the analysis of data from retrospective studies of disease. J Natl Cancer Inst 22:719-48.

MARTÍN DN, ANDREU EP, RAMÍREZ LORCA R, GARCÍA-JUNCO PS, VALLEJO MAROTO I, SANTOS RA, MIRANDA GUISADO ML, GRIJALVO OM, ORTIZ JV, CARNEADO DE LA FUENTE J(2005) G-protein beta-3 subunit gene C825 $\mathrm{T}$ polymorphism: influence on plasma sodium and potassium concentrations in essential hypertensive patients. Life Sci 77:2879-2886.

NEJATIZADEH A, KUMAR R, STOBDAN T, PASHA MQ(2011) Association of GNB3 C825T polymorphism with plasma electrolyte balance and susceptibility to hypertension.Genet Mol Biol 34:553-556.

OSHAUGHNESSY KM(2001). The genetics of essential hypertension. Br J Clin Pharmacol 51:5-11.

POTOCZNA N, WERTLI M, STEFFEN R, RICKLIN T, LENTES KU, HORBER FF(2004) G protein polymorphisms do not predict weight loss and improvement of hypertension in severely obese patients. J Gastrointest Surg 8:862-868.

PUDDU P, PUDDU GM, CRAVERO E, FERRARI E, MUSCARI A(2007) The genetic basis of essential hypertension. Acta Cardiol 62:281-293.

SHIOJI K, KOKUBO Y, MANNAMI T, INAMOTO N, MORISAKI H, MINO Y, TAGOI N, YASUI N, IWAII N(2004) Association between hypertension and the alpha-adducin, beta1-adrenoreceptor, and G-protein beta3 subunit genes in the Japanese population; the Suita study.Hypertens Res 27:31-37.

SIFFERT W, ROSSKOPF D, MORITZ A, WIELAND T, KALDENBERGSTASCH S, KETTLER N, HARTUNG K, BECKMANN S, JAKOBS 
KH(1995) Enhanced G protein activation in immortalized lymphoblasts from patients with essential hypertension. J Clin Invest 96:759-766.

SIFFERT W, ROSSKOPF D, SIFFERT G, BUSCH S, MORITZ A, ERBEL R, SHARMA AM, RITZ E, WICHMANN HE, JAKOBS KH, HORSTHEMKE $\mathrm{B}(1998)$ Association of a human G-protein beta3 subunit variant with hypertension. Nat Genet 18:45-48.

SNAPIR A, HEINONEN P, TUOMAINEN TP, LAKKA TA, KAUHANEN J, SALONEN JT, SCHEININ M(2001) G-protein beta3 subunit C825T polymorphism: no association with risk for hypertension and obesity. J Hypertens 19:2149-55.

SONG F, GILBODY S(1998) Bias in meta-analysis detected by a simple, graphical test. Increase in studies of publication bias coincided with increasing use of meta-analysis. BMJ 316:471.

SUN A, GE J, SIFFERT W, FREY UH (2005) Quantification of allele-specific G-protein beta3 subunit mRNA transcripts in different human cells and tissues by pyrosequencing. Eur J Hum Genet 13:361-369.

SUWAZONO Y, OKUBO $Y$, KOBAYASHI E, MIURA K, MORIKAWA Y, ISHIZAKI M, KIDO T, NAKAGAWA H, NOGAWA K(2004) Lack of association of human G-protein beta 3 subunit variant with hypertension in Japanese workers.J Hypertens.2004;22:493-500.

TAN JC, ZHU ZM, ZHU SJ, YU CQ,WANG L,LIU XL,WANG HY(2003) The relationship between G-protein b3 subunit gene C825T polymorphism and the pathogenesis of essential hypertension. Acta Acad Med Mil Tertiae 25:1381-1384.

TOZAWA Y(2001) G protein beta3 subunit variant: tendency of increasing susceptibility to hypertension in Japanese.Blood Press 10:131-134.

TRIKALINOS TA, SALANTI G, KHOURY MJ, IOANNIDIS JP(2006) Impact of violations and deviations in Hardy-Weinberg equilibrium on postulated gene-disease associations. Am J Epidemiol163:300-309.

TSAI CH, YEH HI, CHOU Y, LIU HF, YANG TY, WANG JC, WANG NM, CHANG JG(2000). G protein beta3 subunit variant and essential hypertension in Taiwan - a case-control study.Int J Cardiol 73:191-195.
WANG H, SUN N, GAO Y, GOU S(2003) G protein beta 3 subunit C825T polymorphism and essential hypertension in Chinese.Beijing Da Xue Xue Bao 35:423-425.

WANG $X$, WANG $S$, LIN $R$, JIANG $X$, CHENG $Z$, TURDI J, DING J WU G, LU X, WEN H(2004) GNB3 gene C825T and ACE gene I/D polymorphisms in essential hypertension in a Kazakh genetic isolate.J Hum Hypertens 18:663-668.

WOOLF B(1955) On estimating the relation between blood group and disease. Ann Hum Genet 19:251-253.

YAMAMOTO M, ABE M, JIN JJ, WU Z, TABARA Y, MOGI M, KOHARA K, MIKI T, NAKURA J(2004) Association of GNB3 gene with pulse pressure and clustering of risk factors for cardiovascular disease in Japanese.Biochem Biophys Res Commun 316:744-748.

YOU T, HUANG JQ, LV JY(2000) Association study of G protein beta3 subunit (GNB3) variants with essential hypertension (in Chinese). Med J Liaoning 14:178-180.

ZHANG J, LI L, ZHANG ZX, CUI TX (2005) Association of G protein beta3 subunit polymorphism with essential hypertension in Chinese. Med Inf 18:358-360.

ZHANG LH (2006) Correlation of 825C/T polymorphism of G-protein beta3 subunit with essential hypertension and concentration of serum vWF Shanxi Medical University, Shanxi p38.

ZHAO HY, CAO J, ZHOU L, WANG B, QIU CC (2009) Genetic analysis of $a-A D D U C I N$ and GNB3 in essential hypertension patient. Basic Clin Med29:394-396.

ZYCHMA MJ, ZUKOWSKA-SZCZECHOWSKA E, OSSOWSKASZYMKOWICZ I, TRAUTSOLT W, GRZESZCZAK W(2000) G-Protein beta(3) subunit C825T variant, nephropathy and hypertension in patients with type 2 (Non-insulin-dependent) diabetes mellitus. Am J Nephrol 20:305-310. 
